\title{
A Newly Developed Electrocatalytic Oxidation and Voltammetric Determination of Curcumin at the Surface of PdNp-graphite Electrode by an Aqueous Solution Process with $\mathrm{Al}^{3+}$
}

\author{
Semiha Çakır, ${ }^{\text {a,* }}$ Ender Biçer, ${ }^{\mathrm{b}}$ and Emine Yılmaz Arslan ${ }^{\mathrm{c}}$ \\ ${ }^{a}$ Department of Chemistry, Faculty of Science, Gazi University, 06500 Teknikokullar, Ankara, Turkey \\ ${ }^{\mathrm{b}}$ Department of Chemistry, Faculty of Arts and Sciences, Ondokuz Mayls University, 55139 Atakum, Samsun, Turkey \\ ${ }^{\mathrm{c}}$ Ministry of Health of Turkey, Turkey Pharmaceuticals and Medical Devices Agency, 06520 Çankaya-Ankara, Turkey
}

\begin{abstract}
In the first stage, the palladium nanoparticles (PdNps)-coated graphite electrode (PdNp/GE) has been prepared. Scanning electron microscopy (SEM) technique showed that the palladium nanoparticles were uniformly distributed with an average particle diameter of 60-75 $\mathrm{nm}$. And then, a novel-modified electrode has been developed by the physical deposition of $\mathrm{Al}^{3+}$ ions on palladium nanoparticles (PdNps)coated graphite electrode $\left(\mathrm{Al}^{3+} / \mathrm{PdNp} / \mathrm{GE}\right)$. This modified electrode was characterized by square-wave voltammetry (SWV), cyclic voltammetry (CV) and electrochemical impedance spectroscopy (EIS). The sensitivities of $\mathrm{PdNp} / \mathrm{GE}$ and $\mathrm{Al}^{3+} / \mathrm{PdNp} / \mathrm{GE}$ electrodes were tested with dopamine. $\mathrm{Al}^{3+} / \mathrm{PdNp} / \mathrm{GE}$ exhibited a catalytic activity for curcumin oxidation. The square-wave voltammogram of curcumin in phosphate buffer $(\mathrm{pH}=2)$ gave an anodic peak at $0.56 \mathrm{~V}$. The anodic peak current of curcumin was found to be linearly related to its concentration in the range of $3.0 \times 10^{-8} \mathrm{M}$ to $6.0 \times 10^{-7} \mathrm{M}$ with a detection limit of $2.2 \times 10^{-8} \mathrm{M}$. It was also found that the novel $\mathrm{Al}^{3+} / \mathrm{PdNp} / \mathrm{GE}$ electrode had the best sensitivity when compared to glassy carbon electrode (GCE), hanging mercury drop electrode (HMDE) and glassy carbon electrode electropolymerized with acid chrome blue K (poly-ACBK/GCE), used for the determination of curcumin. The curcumin was detected in marketed spices sample of turmeric powder. Pure turmeric powder had the highest curcumin concentration, averaging $4.317 \pm 0.175 \%$ by weight.
\end{abstract}

Keywords: modified graphite electrode, $\mathrm{Al}^{3+}$ ion, physical deposition, palladium nanoparticles, curcumin

\section{INTRODUCTION}

Graphite is one of the solid electrodes used in various electroanalytical studies. ${ }^{1-5}$ Its attractive features include access to wide cathodic and anodic potential ranges, low electrical resistance and residual currents, and a reproducible surface structure that can be easily cleaned. ${ }^{5}$ The graphite electrodes have been also used as biological sensors in various studies. ${ }^{1,5}$ However, the nanoparticle-modified electrodes often display unusual physical and catalytic properties, finding huge applicability in the fields of biosensors, medicine, pharmacy and electrocatalysis. ${ }^{5-7}$ The nanomaterials exhibit a high surface-to-volume ratio and a high stability, they are widely available, and they provide fast electron transfer rates. ${ }^{8}$ Therefore, the modification of the graphite electrodes with various nanostructures is an important research field. ${ }^{5,9-13}$
The noble metal nanoparticles were found as ideal supporting materials for the electrocatalytic activities because; they have their own fascinating surface structure, good electrical and mechanical properties, strong stability and limited aggregation and high performance. ${ }^{14}$ Palladium nanoparticles (PdNps) are part of the platinum group of metals, which possess their own special properties for the electrode modification process. ${ }^{14} \mathrm{Pd}$ nanoparticles modified electrodes have been utilized for the electrocatalytic oxidation process of some compounds. ${ }^{15-19}$

Curcumin (1,7-bis[4-hydroxy-3-methoxyphenyl]1,6-heptadiene-3,5-dione) is the main constituent of the perennial herb Curcuma loga (known as turmeric, see Scheme 1). ${ }^{20}$ It has a wide spectrum of pharmacological activities, including antioxidant, ${ }^{21}$ anti-inflammatory, ${ }^{22}$ antitumor, ${ }^{23}$ and anticardiovasculopathic properties. ${ }^{24}$

\footnotetext{
* Author to whom correspondence should be addressed. (E-mail: scakir@gazi.edu.tr)
} 
<smiles>COc1cc(/C=C/C(=O)CC(=O)/C=C/c2ccc(O)c(OC)c2)ccc1O</smiles>

Scheme 1. Chemical structure of curcumin (keto form)

Curcumin can chelate various metal ions and form metal-curcumin complexes. ${ }^{20}$ The metal binding is mediated through its beta-diketone group..$^{20,25}$ It is well known that $\mathrm{Al}^{3+}$ and $\mathrm{Pd}^{2+}$ ions bind to curcumin via the oxygen atoms of the $\beta$-diketone group. ${ }^{26,27}$

In this paper, we present a novel modified graphite electrode by means of the physical deposition of $\mathrm{Al}^{3+}$ ions on the graphite electrode with palladium nanoparticles $\left(\mathrm{Al}^{3+} / \mathrm{PdNp} / \mathrm{GE}\right)$, its characterization and usage in the determination of curcumin.

\section{EXPERIMENTAL}

\section{Reagents}

All compounds were of analytical reagent grade. Curcumin (purity of $98 \%$ ), $\mathrm{PdCl}_{2}$ (purity of $99 \%$ ), and dopamine hydrochloride (purity of $98 \%$ ) were purchased from Sigma-Aldrich. $\mathrm{AlCl}_{3} \cdot 6 \mathrm{H}_{2} \mathrm{O}$ was purchased from Sigma-Aldrich. 0.1 M phosphate buffer solution (abbreviated as PBS) of $\mathrm{pH}=2$ and $0.1 \mathrm{M} \mathrm{KCl}$ solution were used as the supporting electrolyte in the electrochemical experiments, and triple distilled and deionized water was used to prepare the stock solutions.

\section{Apparatus}

For voltammetric and empedimetric measurements, PAR 507 model microcell containing three-electrode system (pencil graphite-working electrode, platinum counter electrode, and $\mathrm{Ag} / \mathrm{AgCl} /$ saturated $\mathrm{KCl}$ reference electrode) along with PAR VersaSTAT 3 potentiostat, including Versastudio and Zsimpwin softwares was used. Pencil graphite electrodes were Tombo leads with a diameter of $0.5 \mathrm{~mm}$, and they were attached to a holder. Electrical contact with the pencil graphite electrode was obtained by soldering a copper wire to the metallic part of the holder. Characterization of electrode surface was carried out using Quanta 400F FE-scanning electron microscopy (SEM).

\section{Procedure}

First of all, the utilization of $\mathrm{Al}^{3+} / \mathrm{PdNp} / \mathrm{GE}$ was tested by dopamine probe according to other electrodes (bare pencil GE and PdNp/GE).

For the determination of curcumin in PBS of $\mathrm{pH}=2$, the specified parameters for the SWV experiments were the following: $E_{\mathrm{i}}, 0.0 \mathrm{~V} ; E_{\mathrm{f}}, 0.85 \mathrm{~V}$; scan rate, $10 \mathrm{mV} / \mathrm{s}$;
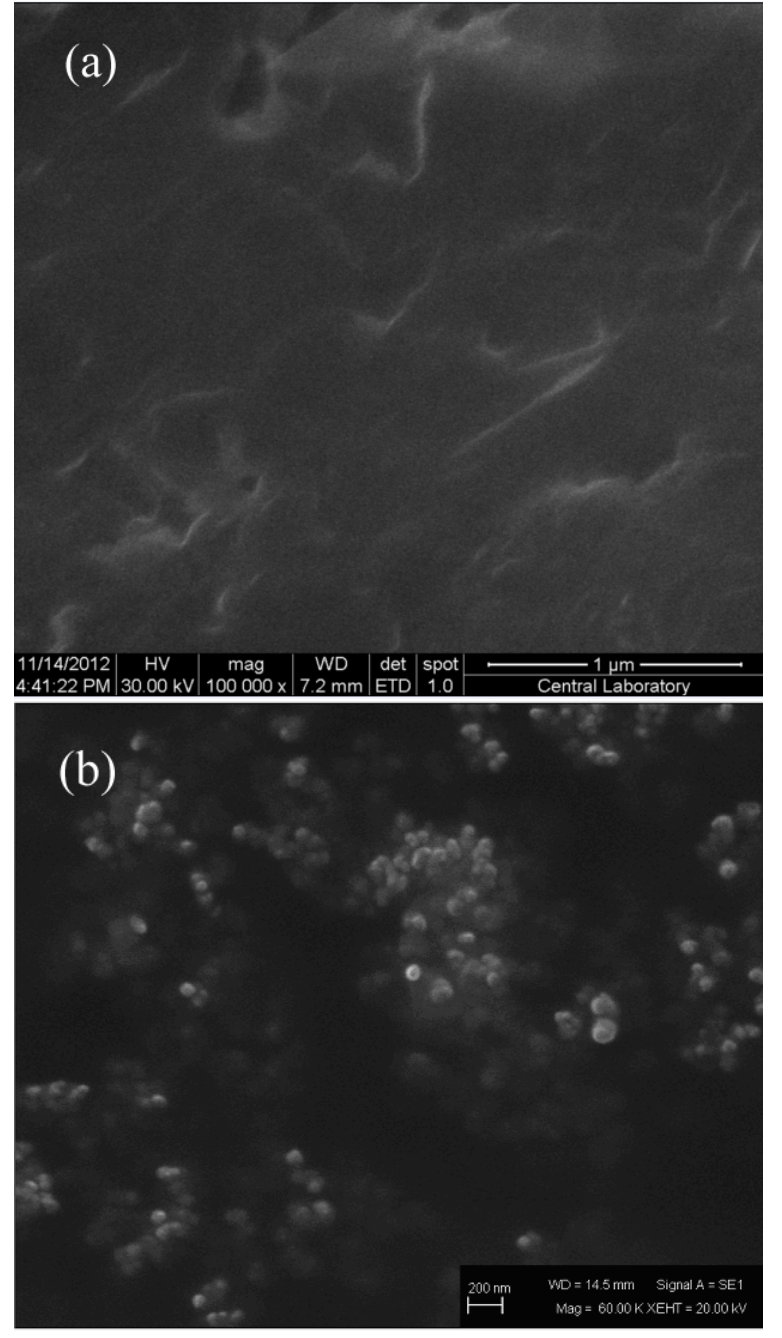

Figure 1. SEM micrographs of GE (a) and PdNp/GE (b) electrodes.

pulse width, $25 \mathrm{~ms}$; pulse period, $200 \mathrm{~ms}$; and pulse amplitude, $10 \mathrm{mV}$. The electrochemical cell contained a $\mathrm{PdNp} / \mathrm{GE}$ or $\mathrm{Al}^{3+} / \mathrm{PdNp} / \mathrm{GE}$ as a working electrode, a $\mathrm{Pt}$ wire counter electrode, and $\mathrm{Ag} / \mathrm{AgCl}(3 \mathrm{M} \mathrm{KCl})$ reference electrode.

\section{Modified Electrode Preparations}

Firstly, graphite electrode (GE) was modified with palladium nanoparticles by cycling potential between -0.5 and $+1.0 \mathrm{~V}$ for ten cycles at $50 \mathrm{mV} / \mathrm{s}$ in $0.1 \mathrm{M} \mathrm{PBS} \mathrm{(pH}$ =7) containing $1 \times 10^{-3} \mathrm{M} \mathrm{PdCl}_{2}$. Finally, the resulting $\mathrm{PdNp} / \mathrm{GE}$ electrode was cleaned by several rinsing with triple distilled water. SEM micrographs of GE and $\mathrm{PdNp} / \mathrm{GE}$ electrodes are given in Figure 1. Figure $1 \mathrm{~b}$ showed that the palladium nanoparticles were uniform distributed with an average particle diameter of 60-75 $\mathrm{nm}$.

Secondly, physical deposition of aluminum ions on $\mathrm{PdNp} / \mathrm{GE}$ electrode was carried out by immersing of the electrode to B-R buffer solution $(\mathrm{pH}=4)$, including 


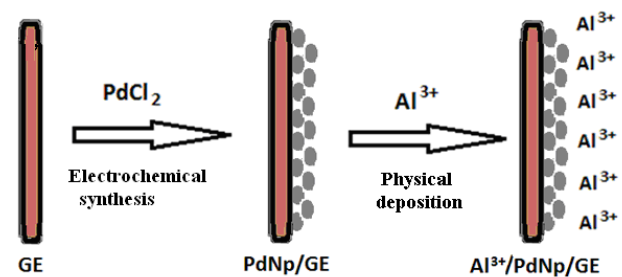

Figure 2. The two-step procedure of $\mathrm{Al}^{3+} / \mathrm{PdNp} / \mathrm{GE}$ modified electrode.

$1 \times 10^{-3} \mathrm{M} \mathrm{AlCl}_{3}$, for $600 \mathrm{~s}$. As shown in Figure 2, the modified electrodes were obtained by a two-step strategy.

\section{RESULTS AND DISCUSSION}

\section{Characterization of the $\mathrm{Al}^{3+} / \mathrm{PdNp} / \mathrm{GE}$ Modified Electrode}

First of all, the palladium nanoparticles were electrodeposited onto GE. SEM and voltammetric techniques (SWV and CV) were used to the investigation of

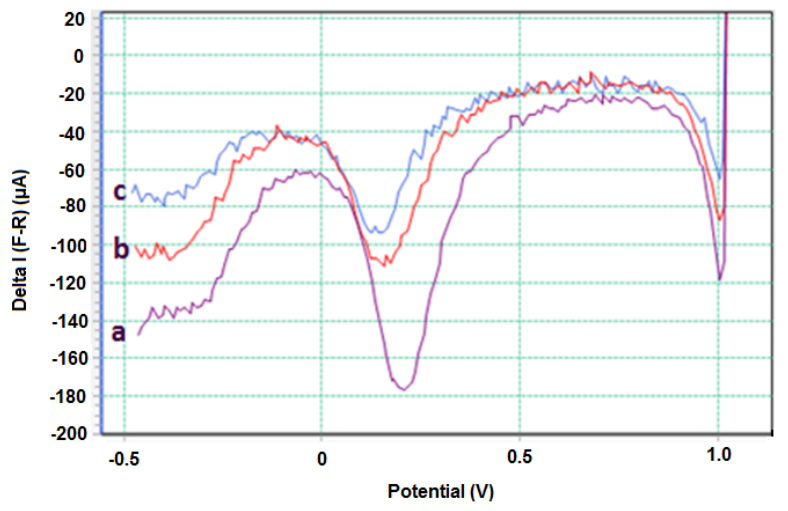

Figure 3. Square-wave voltammograms in $\mathrm{PBS}$ of $\mathrm{pH}=7$ between -0.5 and $+1.0 \mathrm{~V}$ recorded at $\mathrm{PdNp} / \mathrm{GE}$ (a), once $\mathrm{Al}^{3+}$ deposited PdNp/GE (b), twice $\mathrm{Al}^{3+}$ deposited PdNp/GE (c) electrode.

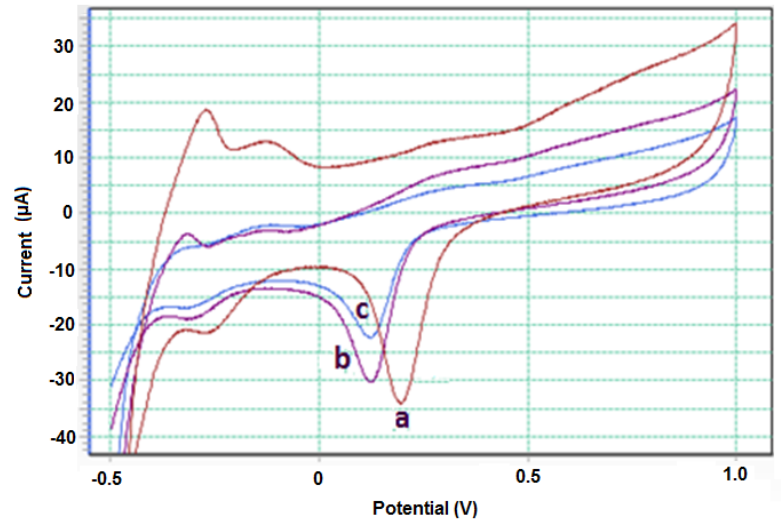

Figure 4. Cyclic voltammograms in $\mathrm{PBS}$ of $\mathrm{pH}=7$ between -0.5 and $+1.0 \mathrm{~V}$ recorded at $\mathrm{PdNp} / \mathrm{GE}$ (a), once $\mathrm{Al}^{3+}$ deposited PdNp/GE (b), twice $\mathrm{Al}^{3+}$ deposited PdNp/GE (c) electrode.

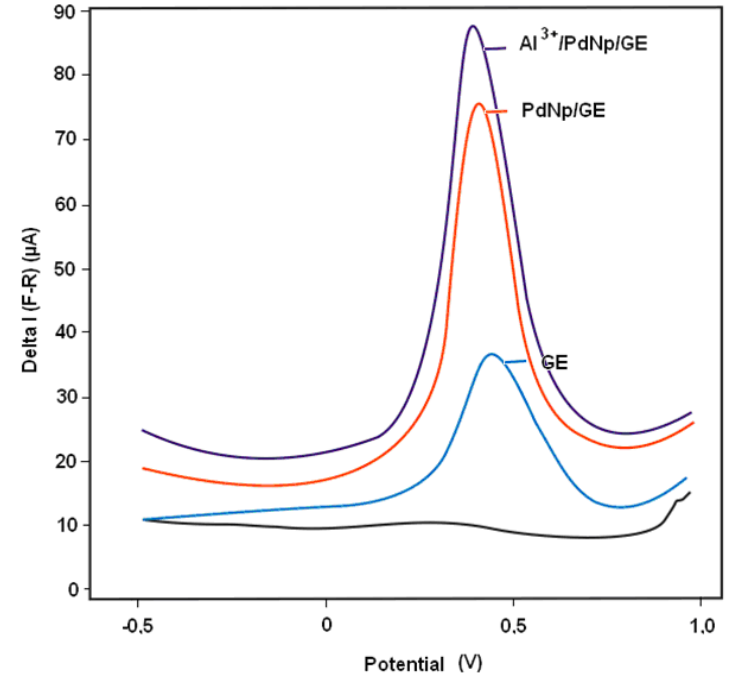

Figure 5. The square-wave voltammograms of $1 \times 10^{-6} \mathrm{M}$ dopamine on different electrodes in PBS of $\mathrm{pH}=7$. The bottom line (black): $10.0 \mathrm{~mL}$ blank (in PBS of $\mathrm{pH}=7$ ).

deposition of palladium nanoparticles on GE surface (Figures 1, 3 and 4).

Figures 3 and 4 show the square-wave and cyclic voltammograms, obtained with $\mathrm{PdNp} / \mathrm{GE}$ and $\mathrm{Al}^{3+} /$ $\mathrm{PdNp} / \mathrm{GE}$ electrodes. Here, the voltammograms with $\mathrm{PdNp} / \mathrm{GE}$ show the characteristic current features for Pd reduction $(0.2 \mathrm{~V}) .^{28}$ However, at $\mathrm{Al}^{3+} / \mathrm{PdNp} / \mathrm{GE}$ electrodes, the current of Pd reduction decreased and its potential shifted to less positive values. Moreover, with increasing $\mathrm{Al}^{3+}$ deposition times, Pd reduction current also decreased. These experimental results indicated that $\mathrm{PdNp} / \mathrm{GE}$ electrode surface was coated by $\mathrm{Al}^{3+}$ ions.

The $\mathrm{PdNp} / \mathrm{GE}$ and $\mathrm{Al}^{3+} / \mathrm{PdNp} / \mathrm{GE}$ were performed by SWV, CV and electrochemical impedance spectroscopy (EIS) techniques. The square-wave voltammograms of $0.1 \mathrm{M}$ PBS $(\mathrm{pH}=7)$ containing $1 \times 10^{-6} \mathrm{M}$ dopamine at $\mathrm{GE}, \mathrm{PdNp} / \mathrm{GE}$ and $\mathrm{Al}^{3+} / \mathrm{PdNp} / \mathrm{GE}$ were given in Figure 5. As can be seen in Figure 5, at $\mathrm{Al}^{3+} / \mathrm{PdNp} / \mathrm{GE}$ compared with GE and PdNp/GE, not only the anodic peak current of dopamine is higher, but also its anodic peak potential is at less positive potential. The $\mathrm{Al}^{3+}$ ions have important influence on the peak current and peak potential of dopamine. The increased current as well as the negative shift of the anodic peak demonstrated an efficient catalytic oxidation of dopamine on the $\mathrm{Al}^{3+} / \mathrm{PdNp} / \mathrm{GE}$, as in other similar studies. ${ }^{29,30}$ This result also clearly showed that the catalytic performance of $\mathrm{Al}^{3+} / \mathrm{PdNp} / \mathrm{GE}$ was better than that of $\mathrm{PdNp} / \mathrm{GE}$ for oxidation of dopamine.

The cyclic voltammograms of dopamine exhibited a reversible peak couple at different scan rates at $\mathrm{Al}^{3+} / \mathrm{PdNp} / \mathrm{GE}$ (Figure 6). The plots of anodic peak current of dopamine $v$ s. scan rate for GE, PdNp/GE and $\mathrm{Al}^{3+} / \mathrm{PdNp} / \mathrm{GE}$ were given in Figure 7 . The anodic peak currents linearly increased by increasing scan rates 
Table 1. Electrochemical parameters of the bare GE, $\mathrm{PdNp} / \mathrm{GE}$, and $\mathrm{Al}^{3+} / \mathrm{PdNp} / \mathrm{GE}$ electrodes in $0.1 \mathrm{M} \mathrm{KCl}$ supporting electrolyte containing $1 \times 10^{-6} \mathrm{M}$ dopamine

\begin{tabular}{ccccccc}
\hline Electrode & $R_{\mathrm{s}} / \Omega$ & $R_{\mathrm{ct}} / \Omega$ & $C_{\mathrm{dl}} / \mathrm{F}$ & $Y / \mathrm{mS}$ & $W / \mathrm{S} \mathrm{s}^{-1}$ & $k_{\mathrm{ct}} / \mathrm{cm} \mathrm{s}^{-1}$ \\
\hline $\mathrm{GE}$ & 117.49 & 15198.5 & $1.52 \times 10^{-5}$ & 3.25 & $3 \times 10^{-4}$ & $3.50 \times 10^{-9}$ \\
$\mathrm{PdNp} / \mathrm{GE}$ & 89.95 & 8109.6 & $2.85 \times 10^{-5}$ & 4.38 & $4 \times 10^{-4}$ & $6.56 \times 10^{-9}$ \\
$\mathrm{Al}^{3+} / \mathrm{PdNp} / \mathrm{GE}$ & 73.11 & 5333.0 & $4.12 \times 10^{-5}$ & 5.25 & $5 \times 10^{-4}$ & $9.98 \times 10^{-9}$ \\
\hline
\end{tabular}

(Figure 7). This result verified that the electrode processes of dopamine have the adsorption characteristics. However, the slope value for $\mathrm{Al}^{3+} / \mathrm{PdNp} / \mathrm{GE}$ was higher than the values of GE and $\mathrm{PdNp} / \mathrm{GE}$.

The EIS was used to follow the impedance changes of the electrode surface in the modification process. Figure 8 shows the EIS plots for GE, PdNp/GE and $\mathrm{Al}^{3+} / \mathrm{PdNp} / \mathrm{GE}$ in $0.1 \mathrm{M} \mathrm{KCl}$ supporting electrolyte containing $1 \times 10^{-6} \mathrm{M}$ dopamine. From the plots in Figure 8, electrochemical parameters such as electron transfer resistance $\left(R_{\mathrm{ct}}\right)$, solution resistance $\left(R_{\mathrm{s}}\right)$, capacitance $\left(C_{\mathrm{dl}}\right)$, and electron transfer rate constant $\left(k_{\mathrm{ct}}\right)$ could be easily found. Optimal experimental parameters for EIS were selected as the frequency range of $0.1-10000 \mathrm{~Hz}$ and a constant potential of $0.35 \mathrm{~V}$. Electrochemical parameters, obtained from the EIS experiments, were presented in Table 1. The Nyquist plots of the bare GE, $\mathrm{PdNp} / \mathrm{GE}$ and $\mathrm{Al}^{3+} / \mathrm{PdNp} / \mathrm{GE}$ are seen in Figure $8 \mathrm{~b}$. It is known that the Nyquist plot of EIS is composed of a semicircle portion and a linear portion, with the former at higher frequencies corresponding to the electron transfer limited process and the latter at lower frequencies related to the diffusion process. ${ }^{31,32}$ The diameter of the semicircle equals to the surface charge transfer resistance $\left(R_{\mathrm{ct}}\right),{ }^{32,33}$ and $R_{\mathrm{ct}}$ value depends on the dielectric and insulating properties of the electrode/electrolyte solution interface. ${ }^{33-35}$

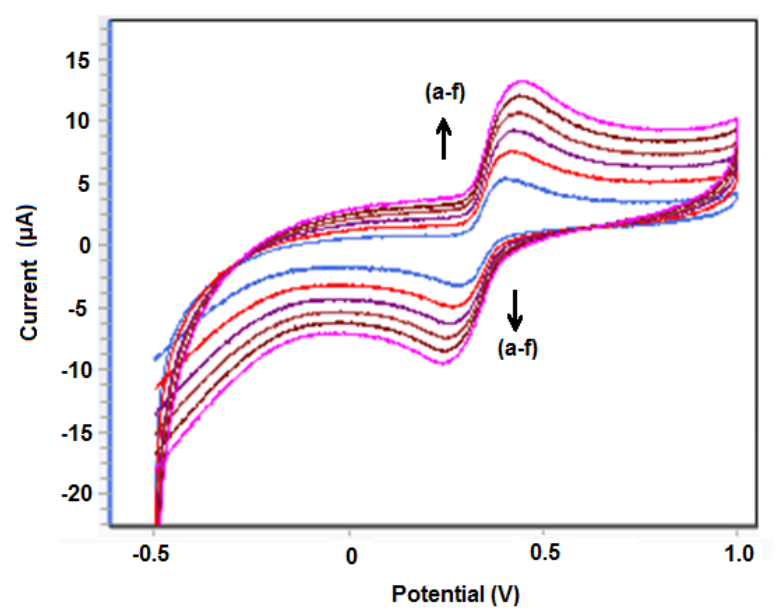

Figure 6. The cyclic voltammograms of $1 \times 10^{-6} \mathrm{M}$ dopamine for different scan rates $\left(v, \mathrm{a} \rightarrow \mathrm{f:}: 25,50,75,100,125,150 \mathrm{mVs}^{-1}\right)$ on $\mathrm{Al}^{3+} / \mathrm{PdNp} / \mathrm{GE}$ electrode in $\mathrm{PBS}$ of $\mathrm{pH}=7$.
The $R_{\text {ct }}$ values of $\mathrm{GE}, \mathrm{PdNp} / \mathrm{GE}$ and $\mathrm{Al}^{3+} / \mathrm{PdNp} /$ GE were found to be 15198.5, 8109.6 and 5333.0 $\Omega$, respectively (Table 1). As shown in Table 1, the charge transfer resistances $\left(R_{\mathrm{ct}}\right)$ were decreased upon the stepwise formation of the modified electrodes. The significant decreases in the $R_{\mathrm{ct}}$ values showed that PdNps and especially $\mathrm{Al}^{3+}$ ions played an important role in accelerating the transfer of the electrons.

The solution resistance, $R_{\mathrm{s}}$, represents the bulk properties of the electrolyte solution. $R_{\mathrm{s}}$ values showed also changes in the turn of $\mathrm{GE}>\mathrm{PdNp} / \mathrm{GE}>$ $\mathrm{Al}^{3+} / \mathrm{PdNp} / \mathrm{GE}$ due to the probable penetration of $\mathrm{Al}^{3+}$ ions adsorbed through $\mathrm{PdNps}$ and increase in surface geometric area. ${ }^{36}$

The highest $C_{\mathrm{dl}}$ value of $\mathrm{Al}^{3+} / \mathrm{PdNp} / \mathrm{GE}$ showed noticeable increase in values of electron transfer rate constant compared with GE and PdNp/GE (Table 1). This result also indicated that the electron transfer process on the $\mathrm{Al}^{3+} / \mathrm{PdNp} / \mathrm{GE}$ is easier and faster than those on the $\mathrm{PdNp} / \mathrm{GE}$ and GE.

The equivalent models of the circuit, evaluated by employing the ZsimpWin software from Princeton Applied Research, were given in Figure 9.

\section{Electrochemical Behavior of Curcumin at $\mathbf{p H}=2$ on the $\mathrm{Al}^{3+} / \mathrm{PdNp} / \mathrm{GE}$ and $\mathrm{PdNp} / \mathrm{GE}$}

Electrochemical behaviors of curcumin in PBS of $\mathrm{pH}=$ 2.0 on the $\mathrm{Al}^{3+} / \mathrm{PdNp} / \mathrm{GE}$ and $\mathrm{PdNp} / \mathrm{GE}$ were studied

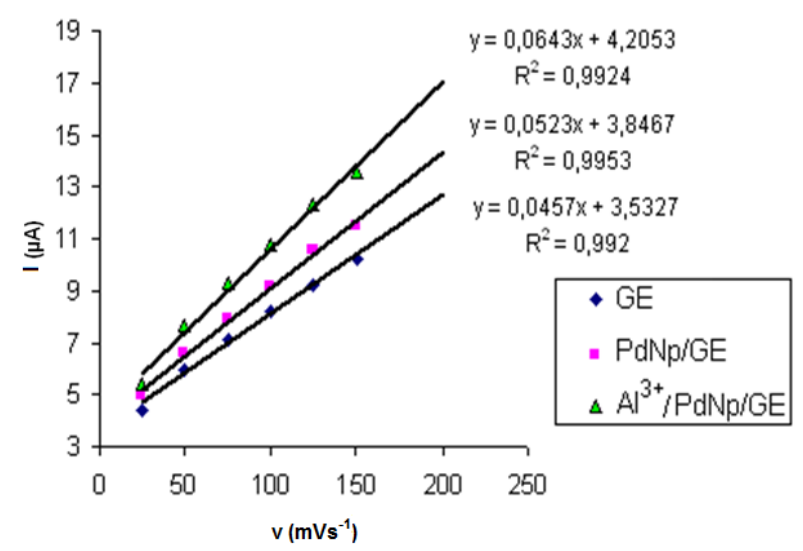

Figure 7. The plots of variation of anodic peak current $\left(I_{\mathrm{pa}}\right)$ of $1 \times 10^{-6} \mathrm{M}$ dopamine with scan rate, $v$ for different electrodes in $\mathrm{PBS}$ of $\mathrm{pH}=7$. 
(Figure 10). Curcumin exhibited an oxidation peak at $0.54 \mathrm{~V}$ on these electrodes. However, the best current response was obtained with $\mathrm{Al}^{3+} / \mathrm{PdNp} / \mathrm{GE}$. So, $\mathrm{Al}^{3+} / \mathrm{PdNp} / \mathrm{GE}$ exhibited a high catalytic activity for
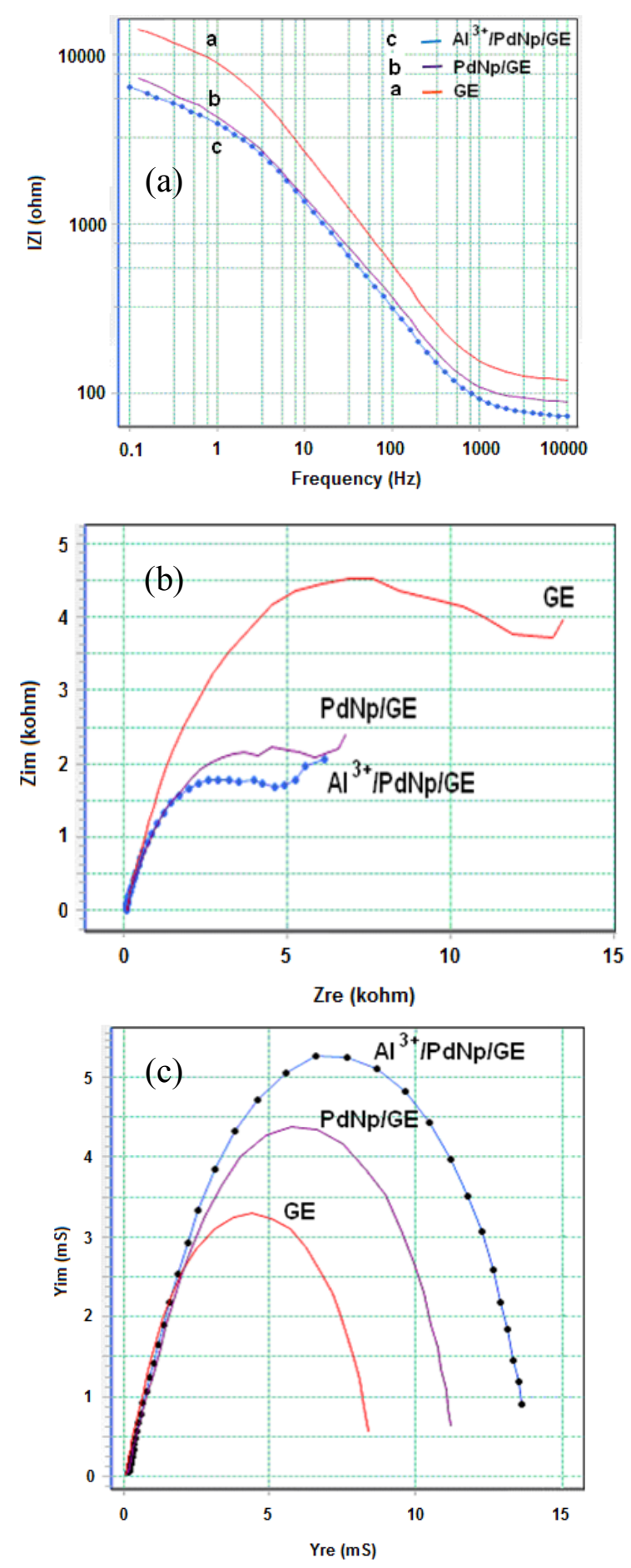

Figure 8. The EIS plots recorded in the presence of $1 \times 10^{-6} \mathrm{M}$ dopamine redox system in $0.1 \mathrm{M} \mathrm{KCl}$ for the $\mathrm{GE}$ (red), $\mathrm{PdNp} / \mathrm{GE}$ (violet) and $\mathrm{Al}^{3+} / \mathrm{PdNp} / \mathrm{GE}$ (blue). Frequency$|Z|$ (a), $Z_{\text {re- }} Z_{\text {im }}\left(\right.$ b), $Y_{\text {re }}-Y_{\text {im }}$ (c).

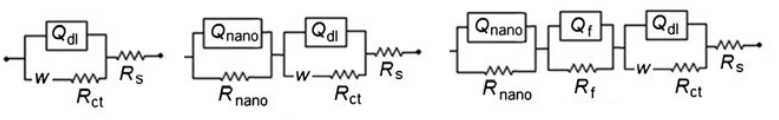

a

b

c

Figure 9. Equivalent circuits for the GE $\left(\chi 2=1.50 \times 10^{-3}\right)$ (a), $\mathrm{PdNp} / \mathrm{GE}\left(\chi^{2}=4.28 \times 10^{-4}\right)(\mathrm{b}), \mathrm{Al}^{+3} / \mathrm{PdNp} / \mathrm{GE}\left(\chi^{2}=1.58 \times 10^{-4}\right)$ (c) $\left(R_{\mathrm{s}}\right.$ the solution resistance, $R_{\mathrm{ct}}$ electron transfer resistance, $Q_{\mathrm{dl}}$ electrode/electrolyte interface capacitance, $R_{\mathrm{f}}$ film resistance, $Q_{\mathrm{f}}$ film capacitance, $R_{\text {nano }}$ metal nanoparticles resistance, $Q_{\text {nano }}$ electrolyte/metal nanoparticles interface capacity, $W$ Warburg impedance resulting from diffusion).

oxidation of curcumin. The results indicated that the electrocatalytic performance of $\mathrm{Al}^{3+} / \mathrm{PdNp} / \mathrm{GE}$ was much better than that of $\mathrm{PdNp} / \mathrm{GE}$. It was also observed that the $\mathrm{Al}^{3+}$ ions can effectively enhance the electrocatalysis effect of palladium nanoparticles.

Cyclic voltammogram of curcumin in PBS of $\mathrm{pH}=2$ on the $\mathrm{Al}^{3+} / \mathrm{PdNp} / \mathrm{GE}$ surface exhibits an anodic peak $(0.56 \mathrm{~V})$ and two cathodic peaks at 0.50 and $0.30 \mathrm{~V}$, respectively (Figure 11). The similar results were obtained by Manaia et al. ${ }^{37}$ at a glassy carbon electrode. The peak at $0.56 \mathrm{~V}$ related to the oxidation process of curcumin. However the peaks at 0.50 and $0.30 \mathrm{~V}$ can be attributed to the reduction of the different oxidation products of curcumin. ${ }^{37}$ According to the literature, ${ }^{37}$ the redox reactions for the voltammetric signals of curcumin may be given in Scheme 2.

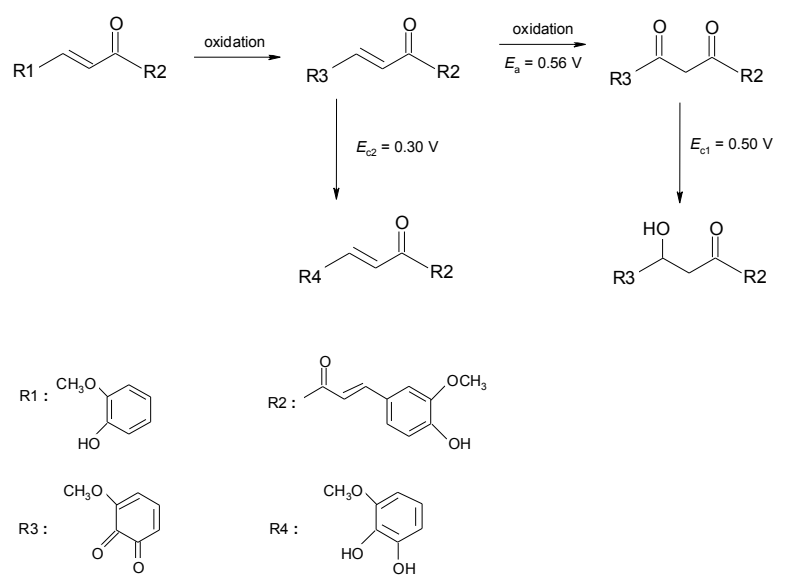

Scheme 2. The proposed electrode reactions for curcumin ${ }^{37}$

The effect of the scan rate $(v, 25-1000 \mathrm{mV} / \mathrm{s})$ on $I_{\mathrm{pa}}$ and $I_{\mathrm{pc}}$ values of reversible peak at $0.56 \mathrm{~V}$ was studied by CV (Figure 11). CV is a very useful electrochemical technique for determining the characteristics of electrode processes. The currents of anodic and cathodic peaks are proportional to $v$ (Figure 11). According to the above results, the electrode process of curcumin on $\mathrm{Al}^{3+} / \mathrm{PdNp} / \mathrm{GE}$ is adsorption-controlled. 


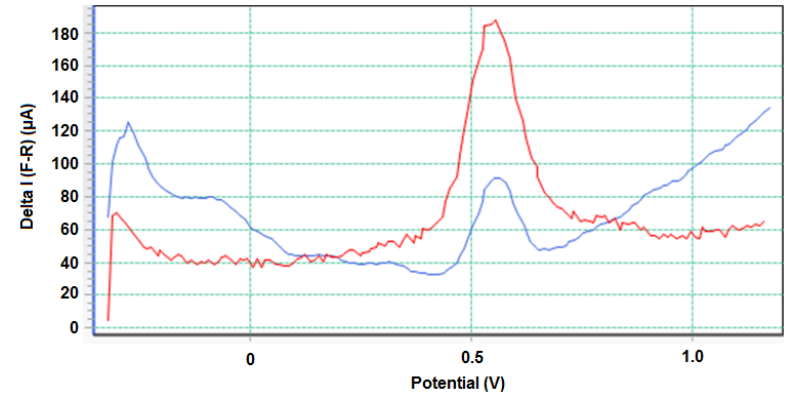

Figure 10. The square-wave voltammograms of $8 \times 10^{-7} \mathrm{M}$ curcumin on $\mathrm{PdNp} / \mathrm{GE}$ (blue line), and $\mathrm{Al}^{3+} / \mathrm{PdNp} / \mathrm{GE}$ (red line) in PBS of $\mathrm{pH}=2$.

\section{Determination of Curcumin at the $\mathrm{Al}^{3+} / \mathrm{PdNp} / \mathrm{GE}$}

The reproducibility of intra- and inter-electrodes $\left(\mathrm{Al}^{3+} /\right.$ $\mathrm{PdNp} / \mathrm{GE}$ ) was performed and also the percent relative standard deviations (RSD \%) of intra- and interelectrodes $\left(\mathrm{Al}^{3+} / \mathrm{PdNp} / \mathrm{GE}\right)$ were calculated as 5.04 (for 5 repetitive measurements on the same electrode) and 6.90 (for 5 independent electrodes), respectively.

The reversible oxidation peak of curcumin at $\mathrm{pH}=$ 2 was changed linearly corresponding to its concentration (Figure 12). The calibration plot of curcumin (Figure 12B) was linearly related to the concentration $(C)$ over the range of $3.0 \times 10^{-8}$ to $6.0 \times 10^{-7} \mathrm{M}$ with the regression equation of Equation (1):

$I_{\mathrm{pa}} / \mu \mathrm{A}=(3.04 \pm 0.02) \times 10^{8} C / \mathrm{M}+34.70 \pm 2.05$

and the coefficient of determination, $R^{2}$, was 0.996 . Limit of detection (LOD) and limit of quantification (LOQ) were found to be $2.2 \times 10^{-8} \mathrm{M}$ and $6.7 \times 10^{-8} \mathrm{M}$, respectively. The determination parameters of curcumin for this assay were compared with those of other studies, ${ }^{38-40}$ and the results were presented in Table 2. As can be seen from Table 2, the novel developed $\mathrm{Al}^{3+} / \mathrm{PdNp} / \mathrm{GE}$ can provide an assay with appropriate concentration range and lower LOD. The determination of curcumin in turmeric was performed using $\mathrm{Al}^{3+}$ / $\mathrm{PdNp} / \mathrm{GE}$. The curcumin content of marketed spices sample of turmeric powder was found to be averaging $4.317 \pm 0.175 \%$ by weight.
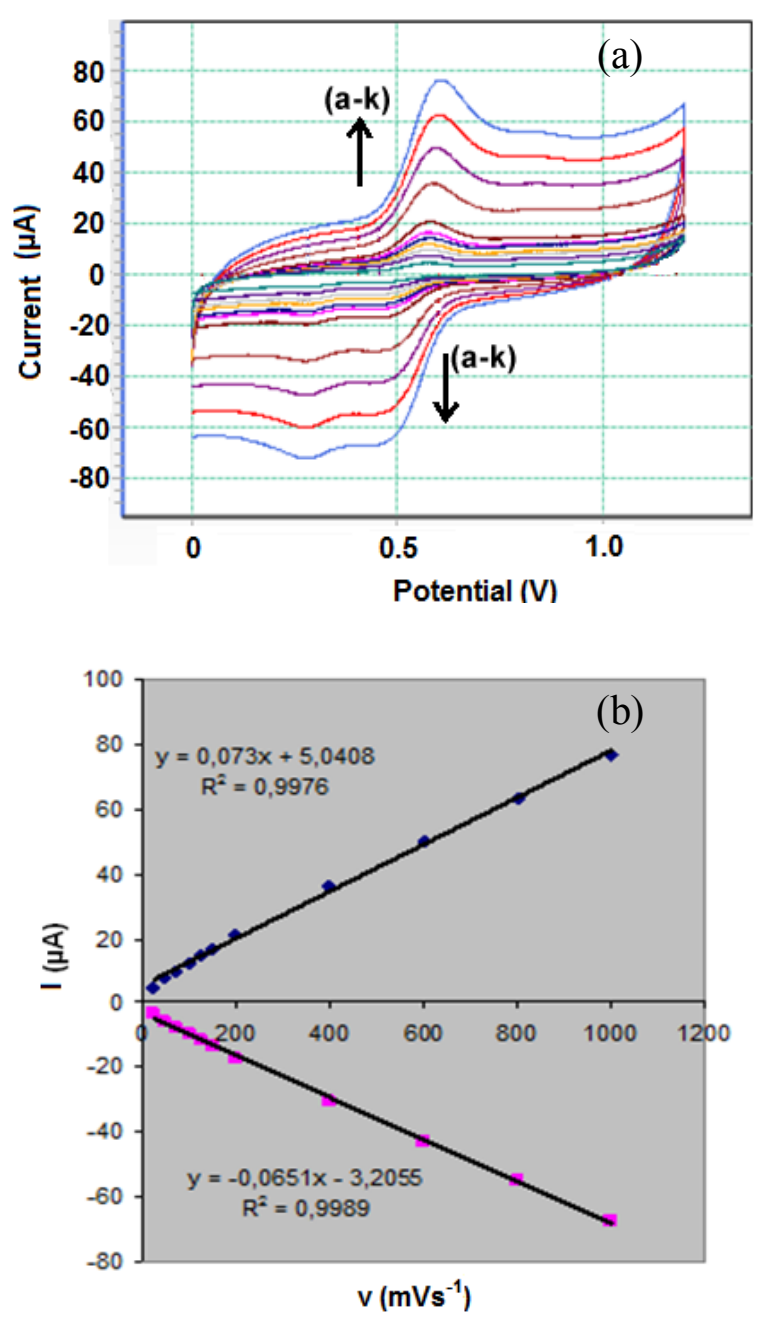

Figure 11. The cyclic voltammograms of $8 \times 10^{-7} \mathrm{M}$ curcumin at different scan rates $(\mathrm{a} \rightarrow \mathrm{k}: 25,50,75,100,125,150,200$, $400,600,800,1000 \mathrm{mVs}^{-1}$ ) on $\mathrm{Al}^{3+} / \mathrm{PdNp} / \mathrm{GE}$ in PBS of $\mathrm{pH}=$ 2 (a), the plots of $I_{\mathrm{pa}}$ and $I_{\mathrm{pc}}$ of $8 \times 10^{-7} \mathrm{M}$ curcumin $v s$. scan rate, $v(b)$.

\section{CONCLUSIONS}

This work reported the preparation and application of a new nanocomposite electrode $\mathrm{Al}^{3+} / \mathrm{PdNp} / \mathrm{GE}$. The electrochemical activities of this electrode have been studied using SWV, CV and EIS techniques. The EIS data

Table 2. Comparison of different electrodes for curcumin determination

\begin{tabular}{ccccc}
\hline Electrode & Method & Linear range / M & LOD / M & Reference \\
\hline GCE & CV & $9.9 \times 10^{-6}-1.1 \times 10^{-4}$ & $4.1 \times 10^{-6}$ & 38 \\
HMDE & DPAdSV & $4.9 \times 10^{-7}-2.8 \times 10^{-5}$ & - & 39 \\
poly-ACBK/GCE & DPV & $1 \times 10^{-7}-7 \times 10^{-5}$ & $4.1 \times 10^{-8}$ & 40 \\
$\mathrm{Al}^{3+} / \mathrm{PdNp} / \mathrm{GE}$ & $\mathrm{SWV}$ & $3.0 \times 10^{-8}-6.0 \times 10^{-7}$ & $2.2 \times 10^{-8}$ & This paper \\
\hline
\end{tabular}



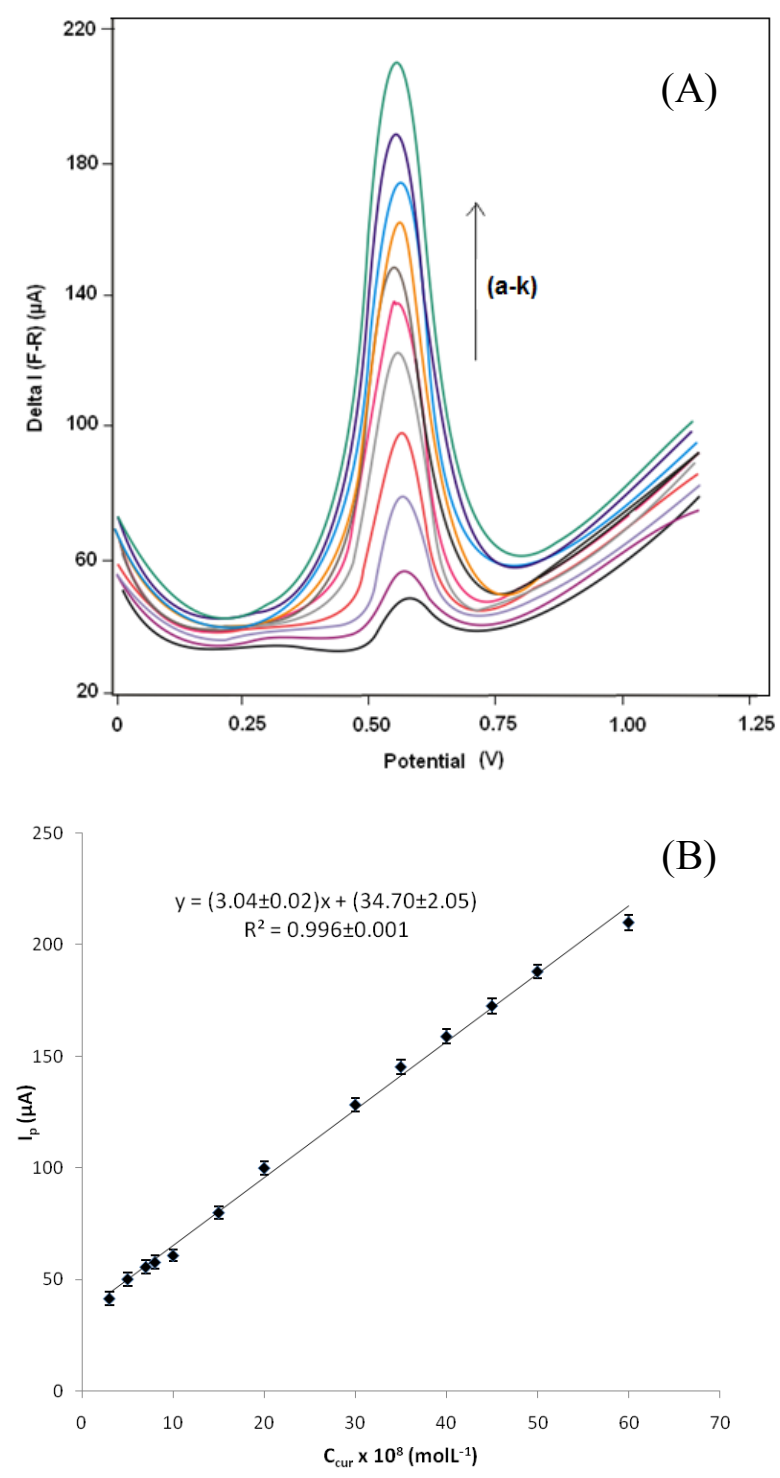

Figure 12. SWVs of different concentrations of curcumin in PBS of $\mathrm{pH}=2$ on $\mathrm{Al}^{3+} / \mathrm{PdNp} / \mathrm{GE}: 5 \times 10^{-8}$ (a), $7 \times 10^{-8}$ (b), $1.5 \times 10^{-7}$ (c), $2 \times 10^{-7}$ (d), $2.5 \times 10^{-7}$ (e), $3 \times 10^{-7}(\mathrm{f}), 3.5 \times 10^{-7}(\mathrm{~g})$, $4 \times 10^{-7}$ (h), $4.5 \times 10^{-7}$ (i), $5 \times 10^{-7}$ (j), $6 \times 10^{-7} \mathrm{M}(\mathrm{k})$ (A). The calibration plot of curcumin (B).

of the modification process indicated that $\mathrm{Al}^{3+}$ and PdNps have been successfully immobilized at the GE surface. Also, the electronic properties of GE showed great difference after the modification with $\mathrm{Al}^{3+}$ ions and PdNps. Based on the EIS and voltammetric studies, we conclude that the $\mathrm{Al}^{3+} / \mathrm{PdNp} / \mathrm{GE}$ exhibited a good electrocatalytic activity for curcumin oxidation at $\mathrm{pH}=2$. The prepared $\mathrm{Al}^{3+} / \mathrm{PdNp} / \mathrm{GE}$ showed a proper linear range $\left(3.0 \times 10^{-8}-6.0 \times 10^{-7} \mathrm{M}\right)$ and low detection limit of $2.2 \times 10^{-8} \mathrm{M}$ by SWV. It is believed that $\mathrm{Al}^{3+} / \mathrm{PdNp} /$ $\mathrm{GE}$ can provide a new research area for the production of new sensitive and selective biosensors.

\section{REFERENCES}

1. M. A. T. Gilmartin and J. P. Hart, Analyst 120 (1995) 10291045 .

2. D. Martorell, F. Cespedes, E. Martinez-Fabregas, and E. Alegret, Anal. Chim. Acta 290 (1994) 343-348.

3. F. Scholz and B. Meyer, Voltammetry of Solid Microparticles Immobilized on Electrode Surfaces, in: A. J. Bard and I. Rubinstein, (Eds.), Electroanalytical Chemistry, A Series of Advances, Marcel Dekker, New York, 1998, vol. 20, pp. 1-86.

4. F. Scholz, U. Schroder, and R. Gulaboski, Electrochemistry of Immobilized Particles and Droplets; Springer, Heidelberg, Berlin, 2005.

5. R. Gulaboski, M. Chirea, C. M. Pereira, M. N. D. S. Cordeiro, R. B. Costa, and A. F. Silva, J. Phys. Chem. C 112 (2008) 24282435 .

6. C. M. Welch, and R. G. Compton, Anal. Bioanal. Chem. 384 (2006) 601-619.

7. D. Hernandez-Santos, M. B. Gonzales-Garcia, and A. C. Garcia, Electroanalysis 14 (2002) 1225-1235.

8. Md. A. Aziz and A.-N. Kawde, Talanta 115 (2013) 214-221.

9. D. Grumelli, C. Vericat, G. Benitez, M. E. Vela, R. C. Salvarezza, L. J. Giovanetti, J. M. Ramallo-Lopez, F. G. Requejo, A. F. Craievich, and Y. S. Shon, J. Phys. Chem. C 111 (2007) 71797184.

10. H. Takele, U. Scurmann, H. Greve, D. Partekar, V. Zaporojtchenko, and F. Faupel, Eur. Phys. J.: Appl. Phys. 33 (2006) 83-89.

11. M. Brust and C. J. Kiely, Colloids Surf. A 202 (2002) 175-186.

12. S. Fullam, D. Cottell, H. Rensmo, and D. Fitzmaurice, Adv. Mater. 12 (2000) 1430-1432.

13. T. Shimizu, T. Teranishi, S. Hasegawa, and M. Miyake, J. Phys. Chem. B 107 (2003) 2719-2726.

14. S. Thiagarajan, R. -F. Yang, S. -M. Chen, Bioelectrochemistry 75 (2009) 163-169.

15. G. Y. Gao, D. J. Guo, and H. L. Li, J. Power Sources 162 (2006) 1094-1098.

16. V. N. Andreev, Russ. J. Electrochem. 42 (2006) 193-196.

17. N. Maleki, A. Safavi, E. Farjami, and F. Tajabadi, Anal. Chim. Acta 611 (2008) 151-155.

18. L. J. Cheng, L. Song, Y. Liu, and B. Dong, Langmuir 17 (2001) 6747-6750.

19. C. B. McAuley, C. E. Banks, A. O. Simm, T. G. J. Jones, and R. G. Compton, Analyst 131 (2006) 106-110.

20. X. Mei, X. Luo, S. Xu, D. Xu, Y. Zheng, S. Xu, and J. Lv, Chemico-Biological Interactions 181 (2009) 316-321.

21. P. Anand, S. G. Thomas, A. B. Kunnumakkara, C. Sundaram, K. B. Harikumar, B. Sung, S. T. Tharakan, K. Misra, I. K. Priyadarsini, K. N. Rajasekharan, and B. B. Aggarwal, Biochem. Pharmacol. 76 (2008) 1590-1611.

22. B. B. Aggarwal and K. B. Harikumar, Int. J. Biochem. Cell B 41 (2009) 40-59.

23. S. Reuter, S. Eifes, M. Dicato, B. B. Aggarwal, M. Diederich, Biochem. Pharmacol. 76 (2008) 1340-1351.

24. A. Goel, A. B. Kunnumakkara, and B. B. Aggarwal, Biochem. Pharmacol. 75 (2008) 787-809.

25. Y. Jiao, J. 4th Wilkinson, E. C. Pietsch, J. L. Buss, W. Wang, R. Planalp, F. M. Torti, and S. V. Torti, Free Radic. Bio. Med. 40 (2006) 1152-1160.

26. M. A. Rodrigues, J. N. Fernandes, R. Ruggiero, and W. Guerra, American Journal of Chemistry 2 (2012) 157-159.

27. F. Ahmadi, A. A. Alizadeh, N. Shahabadi, and M. RahimiNasrabadi, Spectrochimica Acta: Part A 79 (2011) 1466-1474.

28. S. Thiagarajan, R. F. Yang, and S. -M. Chen, Int. J. Electrochem. Sci. 6 (2011) 4537-4552. 
29. L. Fotouhi, M. Fatollahzadeh, and M. M. Heravi, Int. J. Electrochem. Sci. 7 (2012) 3919-3928.

30. L. Fotouhi, A. B. Hashkavayi, and M. M. Heravi, J. Exp. Nanosci. 8 (2013) 947-956.

31. N. Hui, W. Wang, G. Xu, and X. Luo, J. Mater. Chem. B 3 (2015) 556-561.

32. M. Xu, X. Luo, and J. J. Davis, Biosens. Bioelectron. 39 (2013) $21-25$.

33. J. Li, H. Xie, and Y. Li, J. Solid State Electrochem. 16 (2012) 795-802.

34. R. K. Shervedani and M. Bagherzadeh, Electrochim. Acta $\mathbf{5 3}$ (2008) 6293-6303.
35. X. Chen, Y. Wang, J. Zhou, W. Yan, X. Li, and J.-J. Hu, Anal. Chem. 80 (2008) 2133-2140.

36. M. R. Abidian and D. C. Martin, Biomaterials 29 (2008) 12731283.

37. M. A. N. Manaia, V. C. Diculescu, E. S. Gil, and A. M. OliveriaBrett, J. Electroanal. Chem. 682 (2012) 83-89.

38. G. Modi and K. S. Pitre, Defence Sci. J. 60 (2010) 255-258.

39. Z. Stanic, A. Voulgaropoulos, and S. Girousia, Electroanalysis 20 (2008) 1263-1266.

40. J. Peng, K. Nong, and L. Cen, J. Chin. Chem. Soc. 59 (2012) 1415-1420. 